\title{
Stabilizing copper species using zeolite for ethanol catalytic dehydrogenation to acetaldehyde
}

\author{
Dongni Yu a, Weili Dai a,*, Guangjun Wu a, Naijia Guan a,b, Landong Li a,b,\# \\ a School of Materials Science and Engineering \& National Institute for Advanced Materials, Nankai University, Tianjin 300350, China \\ ${ }^{\mathrm{b}}$ Key Laboratory of Advanced Energy Materials Chemistry of the Ministry of Education, Collaborative Innovation Center of Chemical Science and \\ Engineering, Nankai University, Tianjin 300071, China
}

\section{A R T I C L E I N F O}

\section{Article history:}

Received 28 February 2019

Accepted 2 April 2019

Published 5 September 2019

\section{Keywords:}

Ethanol dehydrogenation

Acetaldehyde

Zeolite

Cu-based catalyst

Deactivation

\begin{abstract}
A B S T R A C T
The selective dehydrogenation of ethanol to acetaldehyde is a promising route for acetaldehyde production. Although Cu-based catalysts exhibit high activity in ethanol dehydrogenation, a rapid deactivation due to $\mathrm{Cu}$ sintering always occurs. In this study, highly dispersed $\mathrm{Cu}$ species were stabilized using the silanol defects in Beta zeolite (denoted as Beta) resulting from dealumination, and applied as robust catalysts for ethanol-to-acetaldehyde conversion. Typically, a long catalyst lifetime of $100 \mathrm{~h}$ with an acetaldehyde yield of $\sim 70 \%$ could be achieved over $5 \% \mathrm{Cu} /$ Beta. The presence of $\mathrm{Cu}^{+}$and $\mathrm{Cu}^{0}$ species and the agglomeration of $\mathrm{Cu}$ particles after a long-term reaction for $180 \mathrm{~h}$ were revealed by transmission electron microscopy, thermogravimetric analysis, and CO-diffuse-reflectance infrared Fourier transform spectroscopy, and were responsible for the deactivation of the $\mathrm{Cu}$ /Beta catalyst in the ethanol-to-acetaldehyde conversion.
\end{abstract}

(C) 2019, Dalian Institute of Chemical Physics, Chinese Academy of Sciences. Published by Elsevier B.V. All rights reserved.

\section{Introduction}

Bio-derived ethanol is regarded as a green feedstock to produce valuable chemicals, e.g., ethene, butadiene, 1-butanol, and acetaldehyde [1,2]. Among these chemicals, acetaldehyde is an important building block for the production of acetic acid, acetate esters, and pentaerythritol [3]. In the past few decades, the bioethanol-based dehydrogenation route to produce acetaldehyde and the important hydrogen co-product has attracted significant attention.

Generally, the catalysts for alcohol dehydrogenation can be mainly divided into two types, i.e., metal $(\mathrm{Cu}, \mathrm{Ag}, \mathrm{Pd}, \mathrm{Au}$, etc.) and metal oxide ( $\mathrm{CuO}, \mathrm{ZnO}, \mathrm{MgO}, \mathrm{Cr}_{2} \mathrm{O}_{3}$, etc.) [4-15]. Among these catalysts, $\mathrm{Cu}$-based catalysts exhibit very high activity and good selectivity toward acetaldehyde, in part, because $\mathrm{Cu}$ can cleave $\mathrm{C}-\mathrm{C}$ and $\mathrm{C}-\mathrm{O}$ bonds at much lower rates than other transition metals (e.g., Pd and Pt) [16]. However, a rapid deactivation due to $\mathrm{Cu}$ particle sintering often occurs on $\mathrm{Cu}$-based catalysts $[12,17]$. Hence, special attention has been paid to prevent this $\mathrm{Cu}$ sintering and prolong the catalyst lifetime. Some inert substances that inhibit $\mathrm{Cu}$ sintering have been widely used as textural promoters, and amphoteric or basic metal oxides have been proven to be beneficial for improving the dehydrogenation activity [18-21]. In addition, the effects of the $\mathrm{Cu}$ content and the chemical state of the active $\mathrm{Cu}$ species on the catalytic activity have also been investigated [16,22-27]. Bueno et al. [22] found that the selectivity for the products was related to the metal dispersion defined by the $\mathrm{Cu}$ content. Cassinelli et al.

\footnotetext{
* Corresponding author. Tel/Fax: +86-22-85358536; E-mail: weilidai@nankai.edu.cn

\# Corresponding author. Tel/Fax: +86-22-23500341; E-mail: lild@nankai.edu.cn

This work was supported by the National Natural Science Foundation of China (21872072, 21573113), Municipal Natural Science Foundation of Tianjin (18JCZDJC37400) and Sinopec (417012).

DOI: S1872-2067(19)63378-4 | http://www.sciencedirect.com/science/journal/18722067 | Chin. J. Catal., Vol. 40, No. 9, September 2019
} 
$[23,24]$ reported that $\mathrm{Cu}^{+}$cations were the most active species in the ethanol dehydrogenation reaction, whereas other groups found that the metallic $\mathrm{Cu}$ species were responsible for the ethanol dehydrogenation activity [16,25-27]. Furthermore, the catalytic activity and stability of the catalyst also depend on the nature of the support. A good support should ensure a suitable dispersion of the $\mathrm{Cu}$ active phase, possibly stabilizing it during the high-temperature reaction [28]. Inert $\mathrm{SiO}_{2}$ [11,12], mesoporous carbon [13], silicon carbide [29], and carbon layer-coated $\mathrm{SiO}_{2}$ [15] as well as rice husk ash [17] have already been tested as candidate supports.

In our previous work, zeolite-confined catalyst systems were successfully constructed via a post-synthesis route; they exhibited remarkable activity in ethanol-to-butadiene conversion [30-32]. The silanol groups in the hydroxyl nests of [Si]Beta zeolite acted as the exclusive anchoring sites, and could strongly anchor the cations upon calcination decomposition of the metal precursors. Considering the rapid $\mathrm{Cu}$ sintering of Cu-based catalysts in ethanol-to-acetaldehyde conversion, we expected that the zeolite-confined $\mathrm{Cu}$ /Beta zeolite catalyst will be more structurally stable against $\mathrm{Cu}$ sintering, and exhibit a good performance in the ethanol-to-acetaldehyde conversion. In this study, a Cu/Beta zeolite catalyst was prepared via the post-synthesis route and applied in ethanol-to-acetaldehyde conversion. The effects of the $\mathrm{Cu}$ contents, reaction temperatures, and $\mathrm{Cu}$ precursors on the catalytic performance were investigated. After optimization, a long lifetime of $100 \mathrm{~h}$ with an acetaldehyde yield of $\sim 70 \%$ could be achieved over the $5 \% \mathrm{Cu} /$ Beta zeolite catalyst. The physicochemical properties of the fresh catalysts were analyzed using X-ray diffraction (XRD), nitrogen physisorption, transmission electron microscopy (TEM), ultraviolet-visible spectroscopy (UV-Vis), and $\mathrm{H}_{2}$-temperature-programmed reduction ( $\mathrm{H}_{2}$-TPR). The existing states of $\mathrm{Cu}$ species and the organic deposits occluding the catalyst as a result of the ethanol-to-acetaldehyde conversion were then characterized using TEM, thermogravimetric analysis (TGA), and CO-diffuse-reflectance infrared Fourier transform spectroscopy (CO-DRIFTS). On the basis of the catalytic and spectroscopic results, the deactivation behavior of the $\mathrm{Cu}$ /Beta zeolite catalyst in the ethanol-to-acetaldehyde conversion is discussed herein.

\section{Experimental}

\subsection{Catalyst preparation}

$\mathrm{Cu} /$ Beta zeolite was prepared via a two-step metallation procedure [30]. Firstly, the dealuminated zeolite Si-Beta zeolite was synthesized by treating commercial H-Beta zeolite $\left(n_{\mathrm{Si}} / n_{\mathrm{Al}}\right.$ $=13.5$, Sinopec Co.) in $13 \mathrm{~mol} / \mathrm{L}$ nitric acid aqueous solution. Thereafter, the [Si]Beta host zeolite was impregnated with $\mathrm{Cu}(\mathrm{Ac})_{2} \cdot 6 \mathrm{H}_{2} \mathrm{O}$. Typically, the $\mathrm{Cu}$ precursors were dissolved in excess water to prepare a solution, to which [Si]Beta zeolite was added under stirring for $8 \mathrm{~h}$. Then, the homogenous slurry was evaporated at $80{ }^{\circ} \mathrm{C}$ and calcined at $550{ }^{\circ} \mathrm{C}$ for $6 \mathrm{~h}$ under flowing air. The final product was denoted as $x \% \mathrm{Cu} /$ Beta $(x$ indicates the weight loadings of $\mathrm{Cu}$ metal).

For reference, $\mathrm{Cu}$ /Beta was also prepared using different $\mathrm{Cu}$ precursors via wet impregnation, and the obtained samples were denoted as $\mathrm{CuCl}_{2}$-Beta, $\mathrm{Cu}\left(\mathrm{NO}_{3}\right)_{2}$-Beta, and $\mathrm{Cu}(\mathrm{Ac})_{2}$-Beta (Cu loading: 5\%).

\subsection{Characterization of catalysts}

The XRD patterns of the as-prepared catalysts were recorded on a Rigaku SmartLab powder diffractometer using $\mathrm{Cu} K_{\alpha}$ radiation $(\lambda=1.5418 \AA)$, with a scanning rate of $5^{\circ} / \mathrm{min}$ in the $2 \theta$ range of $5^{\circ}-50^{\circ}$.

The surface areas and pore volumes of the calcined samples were measured using nitrogen adsorption on a Quantachrome iQ-MP gas adsorption analyzer at $-196{ }^{\circ} \mathrm{C}$. Before nitrogen adsorption, the samples were dehydrated at $300{ }^{\circ} \mathrm{C}$ for $6 \mathrm{~h}$. The total surface area was calculated using the Brunauer-Emmett-Teller (BET) equation. The micropore size distribution was determined using the t-plot method.

TEM and high-resolution TEM (HRTEM) images were recorded on a JEOL JEM-2100F electron microscope at an acceleration voltage of $200 \mathrm{kV}$.

$\mathrm{H}_{2}$-TPR experiments on the samples were carried out on a chemisorption analyzer (Chemisorb 2720, Micromeritics) with $5 \mathrm{vol} \% \mathrm{H}_{2} / \mathrm{Ar}$, at a heating rate of $10{ }^{\circ} \mathrm{C} / \mathrm{min}$ from room temperature to $500{ }^{\circ} \mathrm{C}$. Prior to reduction, the samples $(100 \mathrm{mg}$ ) were pretreated under $\mathrm{Ar}$ gas at $350^{\circ} \mathrm{C}$ for $1 \mathrm{~h}$.

The diffuse-reflectance UV-Vis spectra of the $\mathrm{Cu} /$ Beta zeolites were recorded against $\mathrm{BaSO}_{4}$ in the region of 200-800 nm on a PerkinElmer Lambda 750 UV-Vis-NIR spectrophotometer.

${ }^{1} \mathrm{H}$ MAS NMR measurements were performed on a Bruker Avance III spectrometer at a resonance frequency of 400.1 MHz. The ${ }^{1} \mathrm{H}$ MAS NMR spectra were obtained using a single-pulse excitation of $\pi / 2$ with a pulse duration of $2.6 \mu$ s and a repetition time of $20 \mathrm{~s}$. All the ${ }^{1} \mathrm{H}$ MAS NMR studies were performed with dehydrated samples, which were treated at $450{ }^{\circ} \mathrm{C}$ in vacuum (below $10^{-2} \mathrm{~Pa}$ ) for $12 \mathrm{~h}$.

\subsection{Catalyst evaluation}

Ethanol-to-acetaldehyde conversion was performed in a fixed-bed reactor at atmospheric pressure, as described in our previous report. In a typical experiment, $0.4 \mathrm{~g}$ of the $\mathrm{Cu} /$ Beta catalyst (sieve fraction: 20-40 mesh) was placed in the fixed-bed reactor and treated with flowing nitrogen $(20$ $\mathrm{mL} / \mathrm{min}$ ) at $400{ }^{\circ} \mathrm{C}$ for $1 \mathrm{~h}$. After cooling down to the desired temperatures, ethanol was introduced into the reactor, using a Shimadzu LC-2AT Dual Reciprocating Plunger HPLC pump, at a weight hourly space velocity (WHSV) of $1 \mathrm{~h}^{-1}$. The reaction products were analyzed using an on-line gas chromatograph (Shimadzu GC-2010 plus) with a TM-PLOT-Q column and a flame ionization detector (FID). The ethanol conversion and acetaldehyde selectivity were defined as follows:

Ethanol conversion $(\mathrm{mol} \%)=\frac{[\text { Ethanol }]_{\text {inlet }}-[\text { Ethanol }]_{\text {outlet }}}{[\text { Ethanol }]_{\text {inlet }}} \times 100 \%$
Acetaldehyde selectivity $(\mathrm{mol} \%)=\frac{[\text { Acetaldehyde }]_{\text {outlet }}}{[\text { Ethanol }]_{\text {inlet }}-[\text { Ethanol }]_{\text {outlet }}} \times 100 \%$ 


\subsection{TGA and CO-DRIFTS investigations of spent Cu/Beta catalysts}

TGA data were acquired using a Q600 SDT simultaneous thermal analyzer (TA Instruments). Typically, $0.1 \mathrm{~g}$ of spent $\mathrm{Cu} /$ Beta catalyst was placed in an $\mathrm{Al}_{2} \mathrm{O}_{3}$ crucible and heated up to $800{ }^{\circ} \mathrm{C}$ at a constant rate of $10{ }^{\circ} \mathrm{C} / \mathrm{min}$ under flowing $\mathrm{O}_{2} / \mathrm{Ar}$ (20 vol\%/80 vol\%, $30 \mathrm{~mL} / \mathrm{min}$ ).

DRIFTS measurements of the CO adsorption on the spent $\mathrm{Cu} /$ Beta zeolites were conducted on a spectrometer (Bruker Tensor 27), with 128 scans at a resolution of $4 \mathrm{~cm}^{-1}$. The self-supporting pellets of the catalyst samples were placed into the reaction chamber, pretreated under helium flowing at 300 ${ }^{\circ} \mathrm{C}$ for $1 \mathrm{~h}$, and subsequently cooled to $25^{\circ} \mathrm{C}$. Then, $2 \%$ CO (helium balanced) was introduced into the DRIFTS cell at a gas flow rate of $15 \mathrm{~mL} / \mathrm{min}$; subsequently, the cell temperature was increased from 25 to 50 and $100{ }^{\circ} \mathrm{C}$. The DRIFTS spectra were obtained by subtracting the spectrum of the bare catalyst (background).

\section{Results and discussion}

\subsection{Physicochemical properties of catalyst materials}

To verify the possible structural changes during the post-synthesis procedures, the XRD patterns of the parent H-Beta and post-treated samples were collected; they are shown in Fig. 1. The typical diffraction line characteristics of the BEA topology were observed for all the samples, indicating that the primary BEA structure was well-preserved after dealumination and $\mathrm{Cu}$ introduction [33]. In addition, no obvious diffraction lines attributable to $\mathrm{Cu}$ species were observed for the $\mathrm{Cu} /$ Beta zeolites with low $\mathrm{Cu}$ contents (1\%-9\%), indicating that the copper species, which were either amorphous or very small, were highly dispersed within the matrix. These results are consistent with those of the $\mathrm{N}_{2}$ adsorption-desorption analysis; no significant loss in the surface areas and micropore volumes was observed for the samples with low $\mathrm{Cu}$ contents (Table 1). However, upon increasing the $\mathrm{Cu}$ content to $>20 \%$, characteristic peaks of $\mathrm{CuO}\left(35.5^{\circ}\right.$ and $\left.38.9^{\circ}\right)$ appeared [17],

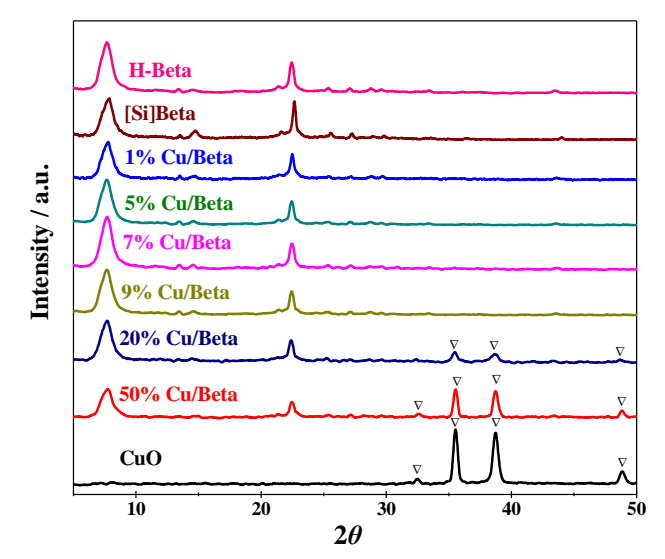

Fig. 1. XRD patterns $\mathrm{H}-\mathrm{Beta},[\mathrm{Si}] \mathrm{Beta}, \mathrm{Cu} /$ Beta and bulk $\mathrm{CuO}$ samples.
Table 1

Chemical composition and surface area of $\mathrm{H}-\mathrm{Beta}$, [Si]Beta and $\mathrm{Cu} / \mathrm{Beta}$ samples under study.

\begin{tabular}{lcccc}
\hline Samples & $\mathrm{Si} / \mathrm{Al}$ a & $\begin{array}{c}\text { Cu loading a } \\
(\mathrm{wt} \%)\end{array}$ & $\begin{array}{c}S_{\mathrm{BET}}{ }^{\mathrm{b}} \\
\left(\mathrm{m}^{2} / \mathrm{g}\right)\end{array}$ & $\begin{array}{c}V_{\text {micro }}{ }^{\mathrm{c}} \\
\left(\mathrm{cm}^{3} / \mathrm{g}\right)\end{array}$ \\
\hline H-Beta & 13.5 & - & 590 & 0.204 \\
[Si]Beta & $>1800$ & - & 620 & 0.210 \\
$1 \% \mathrm{Cu} /$ Beta & $>1800$ & 0.9 & 601 & 0.205 \\
$5 \% \mathrm{Cu} /$ Beta & $>1800$ & 4.9 & 583 & 0.198 \\
$7 \% \mathrm{Cu} /$ Beta & $>1800$ & 6.8 & 571 & 0.192 \\
$9 \% \mathrm{Cu} /$ Beta & $>1800$ & 8.8 & 562 & 0.186 \\
$20 \% \mathrm{Cu} /$ Beta & $>1800$ & 19.7 & 501 & 0.163 \\
$50 \% \mathrm{Cu} /$ Beta & $>1800$ & 49.4 & 458 & 0.141 \\
\hline
\end{tabular}

a Determined by ICP-AES. ${ }^{\mathrm{b}}$ Determined by $\mathrm{N}_{2}$-absorption. ${ }^{\mathrm{c}}$ Micropore volume was estimated by using the t-plot method.

indicating that the small crystallites of $\mathrm{CuO}$ gradually aggregated due to the increase in $\mathrm{Cu}$ content, resulting in an increase in the particle sizes. Simultaneously, the surface areas and micropore volumes of the $\mathrm{Cu} /$ Beta zeolites decreased obviously (Table 1).

On the basis of our previous work, the dealumination of $\mathrm{H}$-Beta and incorporation of $\mathrm{Ti}, \mathrm{Sn}, \mathrm{Zr}$, or Ce species are associated with the evolution of silanols related to the vacant sites during post-synthesis [33-36]. This phenomenon was also observed when preparing the $\mathrm{Cu}$ /Beta zeolites using the wet impregnation method under study. The DRIFTS spectrum (Fig. 2(a)) of the parent H-Beta exhibits two obvious characteristic bands in the hydroxyl stretching region: one band at $3740 \mathrm{~cm}^{-1}$, ascribed to isolated external $\mathrm{Si}-\mathrm{OH}$ groups, and another band at $3600 \mathrm{~cm}^{-1}$, ascribed to the bridging hydroxyl Si-OH-Al [33]. The treatment of $\mathrm{H}-$ Beta with concentrated $\mathrm{HNO}_{3}$ solution resulted in the complete disappearance of the band at $3600 \mathrm{~cm}^{-1}$ associated with $\mathrm{Si}-\mathrm{OH}-\mathrm{Al}$ groups, evidencing the complete elimination of Al from the framework, which was also supported by the higher Si/Al ratio $(>1800)$ of [Si]Beta (Table 1). Simultaneously, intensification of the band at $3735 \mathrm{~cm}^{-1}$ corresponding to isolated internal $\mathrm{Si}-\mathrm{OH}$ groups and the band at $3520 \mathrm{~cm}^{-1}$ related to hydrogen-bonded silanol groups was clearly observed, indicating the formation of vacant $\mathrm{T}$ atom sites, in accordance with earlier assignments [33]. After the introduction of the $\mathrm{Cu}$ species, an obvious decrease in the intensity of the $\mathrm{OH}$ bands at 3735 and $3520 \mathrm{~cm}^{-1}$ occurred. According to our previous studies [30], this observation indicated that catalyst systems of copper species confined in Beta zeolite were successfully constructed via the post-synthesis route. Upon calcination, the $\mathrm{Cu}$ precursors decomposed and reacted with the silanols created by dealumination. Thus, $\mathrm{Cu}$ functional sites could be introduced into zeolite cages, at former $\mathrm{Al}$ positions of the parent zeolite, to build confined catalytic reactors.

The hydroxyl groups in H-Beta, and the Si-Beta zeolites before and after the introduction of $\mathrm{Cu}$ species were analyzed using ${ }^{1} \mathrm{H}$ MAS NMR spectroscopy. As shown in Fig. 2(b), a strong signal at $\delta_{1 \mathrm{H}}=1.5 \mathrm{ppm}$ due to silanol groups at framework defects, and two weak resonance signals at 2.5 and 3.9 ppm ascribable to extra-framework $\mathrm{Al}-\mathrm{OH}$ groups and bridging hydroxyl Si-OH-Al, respectively, appeared for the H-Beta sam- 

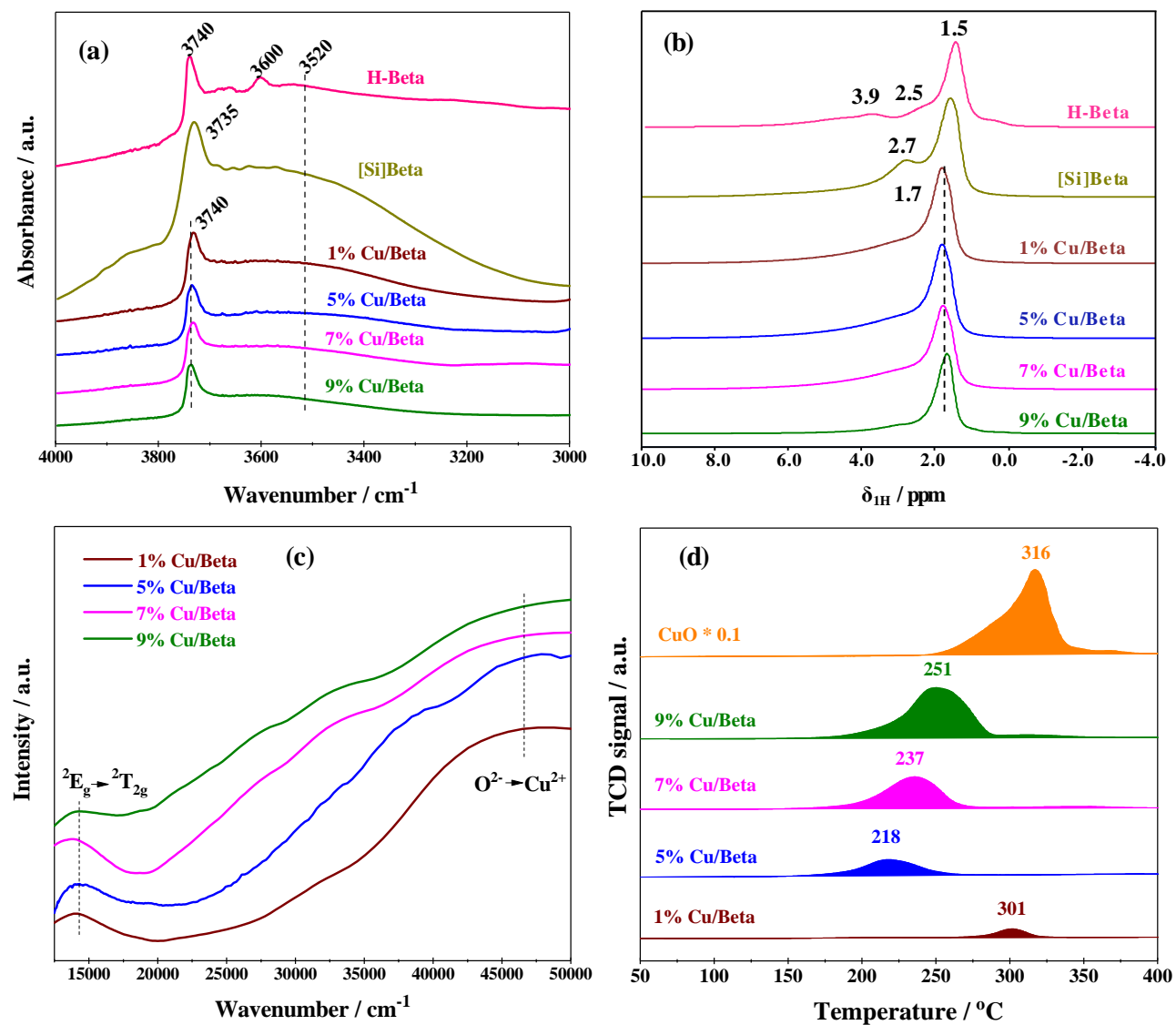

Fig. 2. (a) DRIFT spectra in the hydroxyl stretching vibration region and (b) ${ }^{1} \mathrm{H}$ MAS NMR spectra of $\mathrm{H}-\mathrm{Beta}$, [Si]Beta and Cu/Beta samples; (c) $\mathrm{UV}$-Vis-NIR spectra of $\mathrm{Cu}$ /Beta samples with different $\mathrm{Cu}$ contents; (d) $\mathrm{H}_{2}$-TPR profiles of bulk CuO and $\mathrm{Cu} / \mathrm{Beta}$ zeolite samples with different $\mathrm{Cu}$ contents.

ple [34]. After dealumination, the band of the hydroxyl groups associated with $\mathrm{Al}$ species responsible for the signals at 2.5 and 3.9 ppm disappeared, and a broad signal at about $2.7 \mathrm{ppm}$ due to the hydrogen bonds between some $\mathrm{SiOH}$ groups and neighboring framework oxygen species inside the silanol nests appeared for [Si]Beta [34]. The introduction of $\mathrm{Cu}$ species resulted in the disappearance of the band for silanol groups in the hydroxyl nests, leaving the band for the remaining unreacted silanols located at $1.7 \mathrm{ppm}$, in good agreement with the DRIFTS results in Fig. 2(a). On the basis of the results of DRIFTS and ${ }^{1} \mathrm{H}$ MAS NMR spectroscopy, the $\mathrm{Cu}$ /Beta-confined catalyst systems could be prepared in a way similar to that of $\mathrm{Zn} /$ Beta and Y/Beta in our previous work [30].

The chemical environment of the $\mathrm{Cu}$ species within the [Si]Beta matrix was characterized using UV-Vis-NIR spectroscopy. As shown in Fig. 2(c), two absorption bands centered at about 14000 and $48000 \mathrm{~cm}^{-1}$ appeared for all the $\mathrm{Cu} /$ Beta zeolites. The former band can be attributed to the ${ }^{2} \mathrm{E}_{\mathrm{g}} \rightarrow{ }^{2} \mathrm{~T}_{2 \mathrm{~g}}$ transition of $\mathrm{Cu}^{2+}$ cations in an octahedral environment, whereas the latter can be assigned to $\mathrm{O}^{2-} \rightarrow \mathrm{Cu}^{2+}$ charge transfer transitions, which are characteristic of isolated $\mathrm{Cu}^{2+}[37,38]$. With an increase in the $\mathrm{Cu}$ loadings from $1 \%$ to $9 \%$, the intensities of these bands gradually increased, indicating an increase in the amount of $\mathrm{Cu}^{2+}$ species in the [Si]Beta matrix. Additionally, a broad band in the range of $20000-25000 \mathrm{~cm}^{-1}$, attributable to the $d-d$ transition of $\mathrm{Cu}$ with an octahedral environment in $\mathrm{CuO}$, appeared when the $\mathrm{Cu}$ loading increased to $>5 \%[38,39]$, indicating an increase in the particle size of the $\mathrm{Cu}$ species; this is in good agreement with the TPR results (ut infra).

TPR experiments were performed to evaluate the reducibility of the $\mathrm{Cu} / \mathrm{Beta}$ zeolites. This technique is suitable for studying low-load and highly dispersed systems whose characteristics are beyond the limits of detection of other direct structural analysis methods such as XRD [22]. Fig. 2(d) shows the TPR profiles of the bulk $\mathrm{CuO}$ and $\mathrm{Cu} /$ Beta samples with different $\mathrm{Cu}$ loadings. The maximum of the TPR peaks $\left(T_{\max }\right)$ of the $\mathrm{Cu} /$ Beta samples should have been related to the reduction of supported $\mathrm{Cu}$ species in different interactions with the zeolite matrix as well as to the particle size and $\mathrm{Cu}$ content. Bulk $\mathrm{CuO}$ exhibited a single hydrogen consumption peak centered at $316^{\circ} \mathrm{C}$. For the $\mathrm{Cu} /$ Beta samples, the reduction temperatures were significantly lowered, in good agreement with earlier reports [17,22], due to the presence of highly dispersed $\mathrm{CuO}$ with an octahedral environment. The broadening of the TPR peak and its shift to higher temperatures were related to an increase in the $\mathrm{CuO}$ particle sizes with an increase in the $\mathrm{Cu}$ content from $5 \%$ to 

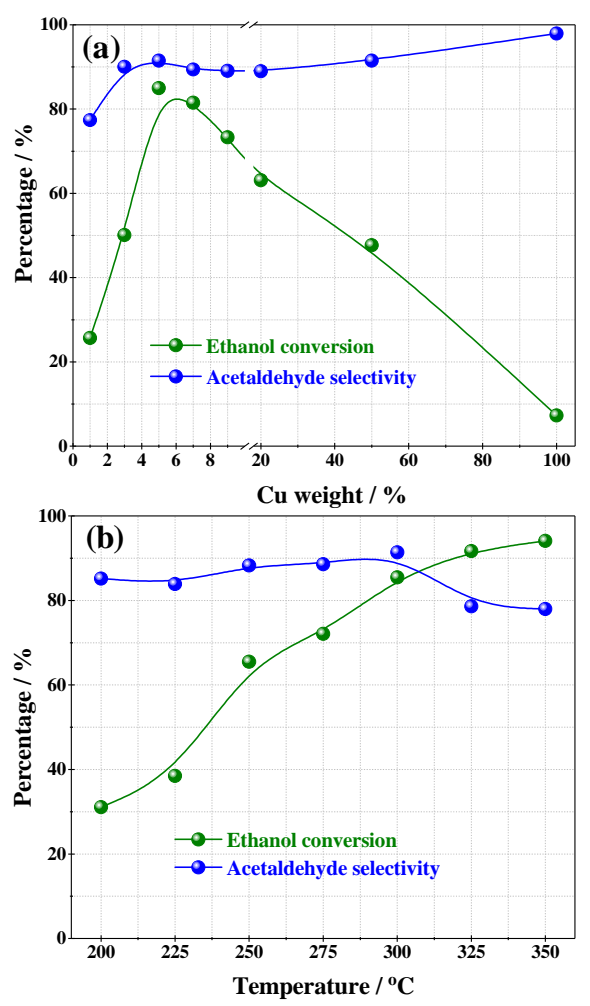

Fig. 3. (a) Ethanol conversion and acetaldehyde selectivity over $\mathrm{Cu} /$ Beta zeolite catalysts with different $\mathrm{Cu}$ contents at $300{ }^{\circ} \mathrm{C}$ with a TOS of $2 \mathrm{~h}$; (b) Ethanol conversion and acetaldehyde selectivity over $5 \% \mathrm{Cu} /$ Beta zeolite catalysts at different temperatures with a TOS of 2 h.

9\%. In addition, $1 \% \mathrm{Cu}$ /Beta exhibited a relatively higher $T_{\max }$ $\left(301{ }^{\circ} \mathrm{C}\right)$ than those of the other samples. This indicated that $\mathrm{Cu} /$ Beta with a very low $\mathrm{Cu}$ content probably contained highly dispersed isolated $\mathrm{Cu}^{2+}$ species that strongly interacted with the support or were possibly incorporated into the zeolite framework, and were hard to reduce.

\subsection{Optimization of catalysts and reaction conditions for ethanol conversion}

The effects of the $\mathrm{Cu}$ contents, reaction temperatures, and $\mathrm{Cu}$ precursors on the ethanol conversion and acetaldehyde selectivity are given in Figs. 3 and 4. The Cu content of the catalyst clearly shows a strong impact on the ethanol conversion (Fig. 3(a)). Upon increasing the $\mathrm{Cu}$ loading from $1 \%$ to $5 \%$, the ethanol conversion dramatically increased from $25 \%$ to $85 \%$. However, a further increase in the $\mathrm{Cu}$ loading from $5 \%$ to $50 \%$ resulted in a gradual decrease in the ethanol conversion (from $85 \%$ to $48 \%$ ). For comparison, the catalytic performance of bulk $\mathrm{CuO}$ was also studied, and a poor activity with $7 \%$ ethanol conversion and $97 \%$ selectivity toward acetaldehyde was achieved. According to earlier studies [16,22], large metal species are not conducive to ethanol conversion. This indicates that when approaching saturation of highly dispersed $\mathrm{Cu}$ species in $5 \% \mathrm{Cu} /$ Beta, more $\mathrm{Cu}$ species will be forced to aggregate into larger $\mathrm{CuO}$ particles, as revealed by the XRD and $\mathrm{H}_{2}$-TPR results. Therefore, lower catalytic activities were observed for the $\mathrm{Cu} /$ Beta catalysts with higher amounts of $\mathrm{Cu}$ loading. In addition, an increase in the $\mathrm{Cu}$ loading had no significant influence on the acetaldehyde selectivity, suggesting that selective dehydrogenation of ethanol to acetaldehyde was the dominant reaction over the $\mathrm{Cu}$ /Beta catalysts.
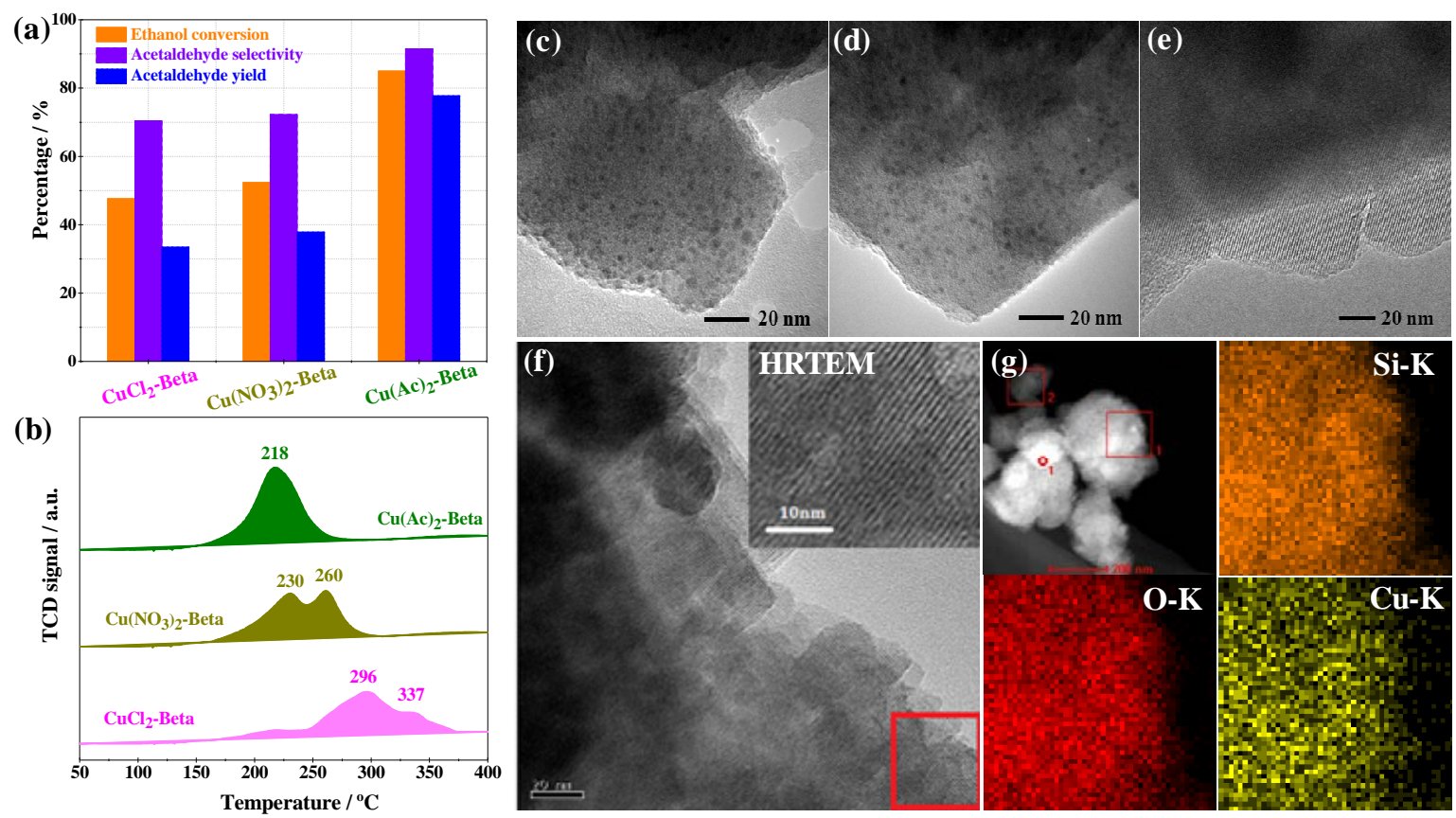

Fig. 4. (a) Catalytic perfpormance of $5 \% \mathrm{Cu} /$ Beta prepared with different precursors in the ethanol to acetaldehyde conversion at $300{ }^{\circ} \mathrm{C}$ with a TOS $=$ $2.0 \mathrm{~h} ; \mathrm{H}_{2}$-TPR profiles (b) and TEM pictures (c and d) of $5 \% \mathrm{Cu} /$ Beta zeolites prepared with different precursors; High-resolution TEM images (f) of $\mathrm{Cu}(\mathrm{Ac})_{2}$-Beta sample with the corresponding element mapping $(\mathrm{g})$. 
Fig. 3(b) shows the ethanol conversion and acetaldehyde selectivity over $5 \% \mathrm{Cu} /$ Beta at reaction temperatures of 200-350 ${ }^{\circ} \mathrm{C}$. Clearly, the ethanol conversion gradually increased from $30 \%$ to $95 \%$ with an increase in the reaction temperature from 200 to $350{ }^{\circ} \mathrm{C}$. Simultaneously, a stable acetaldehyde selectivity of $85 \%-90 \%$ was maintained up to $300{ }^{\circ} \mathrm{C}$; however, it started to decrease at $325^{\circ} \mathrm{C}$, as much more condensation products from acetaldehyde and some ethene from ethanol dehydration were produced. Therefore, $300{ }^{\circ} \mathrm{C}$ was used as the reaction temperature in subsequent studies.

Fig. 4(a) shows the effect of the $\mathrm{Cu}$ precursors, i.e., $\mathrm{CuCl}_{2}$, $\mathrm{Cu}\left(\mathrm{NO}_{3}\right)_{2}$, and $\mathrm{Cu}(\mathrm{Ac})_{2}$, on the ethanol conversion and acetaldehyde selectivity over the $5 \% \mathrm{Cu} /$ Beta catalyst at $300{ }^{\circ} \mathrm{C}$. Obviously, the $\mathrm{Cu}$ precursors had a strong impact on the catalytic performance. The use of inorganic precursors, i.e., $\mathrm{CuCl}_{2}$ and $\mathrm{Cu}\left(\mathrm{NO}_{3}\right)_{2}$, resulted in a lower catalytic activity, with $\sim 50 \%$ ethanol conversion and $\sim 80 \%$ acetaldehyde selectivity, in comparison with that achieved using the organic precursor $\mathrm{Cu}(\mathrm{Ac})_{2}$. The $\mathrm{H}_{2}$-TPR profiles indicated that the use of inorganic precursors would lead to the broadening of the TPR peaks and their shift toward higher temperatures (Fig. 4(b)). This suggested that the $\mathrm{Cu}$ species obtained from the inorganic precursors interacted more strongly with the [Si]Beta matrix or possibly had larger particle sizes. The TEM images of these $\mathrm{Cu} /$ Beta catalysts also indicated that the inorganic precursors could produce larger particles of $\mathrm{Cu}$ species (Fig. 4(c) and (d)), which were not easy to reduce and were not conducive to the ethanol-to-acetaldehyde conversion. For $\mathrm{Cu} /$ Beta prepared with the organic precursor, the HRTEM image showed the clear lattice fringes of the zeolite support but no evidence of large particles of $\mathrm{Cu}$ species on the support (Fig. 4(f)), indicating that $\mathrm{Cu}$ species were homogeneously dispersed in the [Si]Beta matrix. This was also supported by the corresponding element mapping results, which showed that the distribution of the $\mathrm{Cu}$ species was homogeneous and that no obvious $\mathrm{Cu}$-containing aggregates were formed (Fig. 4(g)). Hence, a good catalytic activity could be expected and also achieved for the $\mathrm{Cu}(\mathrm{Ac})_{2}$-Beta catalyst with a homogeneous distribution of $\mathrm{Cu}$ species.

\subsection{Stability of optimal catalyst in ethanol conversion}

Under the optimized reaction conditions (vide supra), i.e., $5 \% \mathrm{Cu} /$ Beta catalyst prepared with $\mathrm{Cu}(\mathrm{Ac})_{2}$ precursor and a reaction temperature of $300{ }^{\circ} \mathrm{C}$, the long-term stability of the catalyst was tested for $180 \mathrm{~h}$, and the results are shown in Fig. 5. For comparison, the stability of bulk $\mathrm{CuO}$ was also studied. Using the $5 \% \mathrm{Cu} /$ Beta catalyst, an initial ethanol conversion of $86 \%$ could be achieved, and it only dropped by $~ 15 \%$ after 100 $\mathrm{h}$ of reaction. Moreover, the acetaldehyde selectivity gradually increased from $82 \%$ to $92 \%$, and a stable acetaldehyde yield of $\sim 70 \%$ could be obtained during the long-term reaction for 100 h. With further progress in the ethanol-to-acetaldehyde conversion, the deactivation of the $5 \% \mathrm{Cu}$ /Beta catalyst occurred, and the ethanol conversion gradually decreased to $\sim 50 \%$ at a time-on-stream (TOS) of $180 \mathrm{~h}$. For the bulk CuO catalyst, although a higher initial acetaldehyde selectivity of $>95 \%$ could

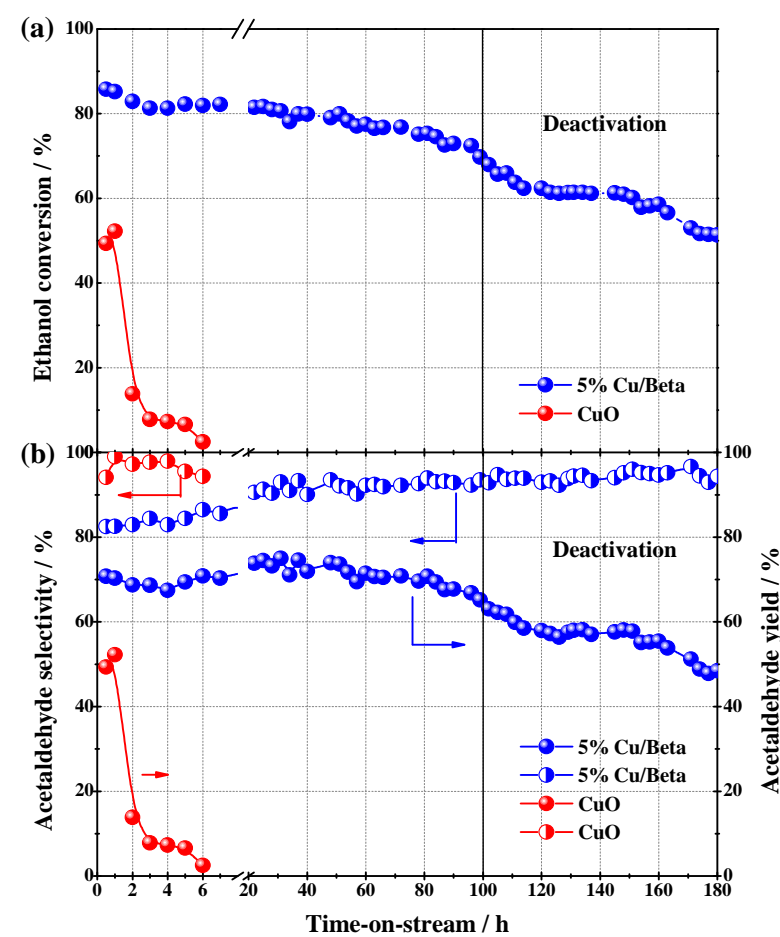

Fig. 5. Ethanol conversion (a) and acetaldehyde selectivity (b) as well as acetaldehyde yields over $5 \% \mathrm{Cu}$ /Beta and bulk $\mathrm{CuO}$ samples during the ethanol to acetaldehyde conversion at $300{ }^{\circ} \mathrm{C}$ with a TOS $=180 \mathrm{~h}$.

be achieved, a rapid deactivation due to $\mathrm{Cu}$ sintering started to occur even at a TOS of $2.0 \mathrm{~h}$, and the ethanol conversion dramatically decreased from $49 \%$ to $2 \%$ over $6 \mathrm{~h}$. These results clearly indicated that $\mathrm{Cu} /$ Beta-confined catalyst systems were successfully constructed via the post-synthesis route, and exhibited good structural stability against $\mathrm{Cu}$ sintering. In addition, by increasing the WHSV from 1.0 to $4.0 \mathrm{~h}^{-1}$, a high acetaldehyde productivity of $1.99 \mathrm{~g}_{\mathrm{AcH}} / \mathrm{g}_{\mathrm{cat}} / \mathrm{h}$ with a stable acetaldehyde selectivity of $84 \%$ (see Table S1 for direct comparison with the literature) could be achieved at $300{ }^{\circ} \mathrm{C}$ over the same $5 \% \mathrm{Cu} /$ Beta catalyst.

The $5 \% \mathrm{Cu}$ /Beta catalyst also exhibited a remarkable activity in propanol dehydrogenation to propylaldehyde; a stable activity with $\sim 92 \%$ propanol conversion and $\sim 95 \%$ propylaldehyde selectivity could be achieved for a TOS of $15 \mathrm{~h}$ (Fig. 6). This suggested that the $\mathrm{Cu} /$ Beta zeolites under study were general dehydrogenation catalysts, and their use could be expanded to the selective conversion of alcohols to the corresponding aldehydes.

To verify the recyclability of $5 \% \mathrm{Cu} /$ Beta, the spent catalyst after ethanol-to-acetaldehyde conversion for $180 \mathrm{~h}$ was regenerated under synthetic air at $550{ }^{\circ} \mathrm{C}$ for $4 \mathrm{~h}$, and its catalytic activity was re-evaluated at $300{ }^{\circ} \mathrm{C}$. In general, the catalytic performance of the regenerated catalyst could be well-recovered if carbon deposits were exclusively responsible for the catalyst deactivation, as shown in Fig. 7; however, a rapid deactivation occurs after a TOS of $10 \mathrm{~h}$. These observations revealed that carbon deposits were associated with the deactivation of the $5 \% \mathrm{Cu}$ /Beta catalyst under study. Other 


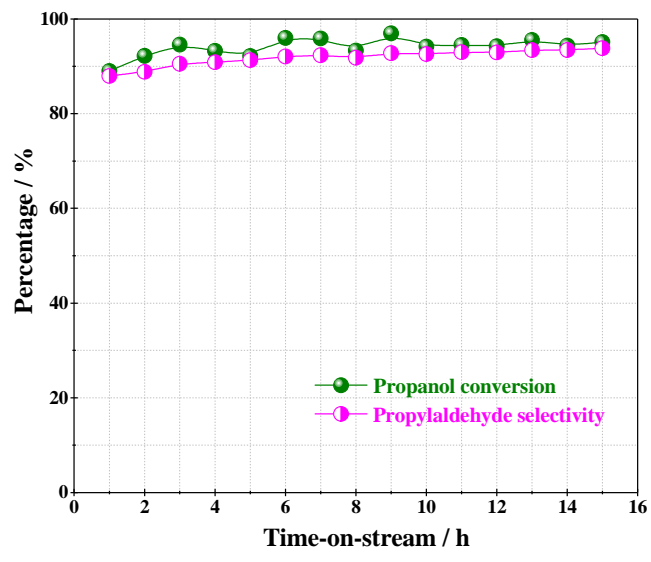

Fig. 6. Propanol conversion and propylaldehyde selectivity over $5 \%$ $\mathrm{Cu} /$ Beta zeolite catalyst during the propanol to propylaldehyde conversion at $300{ }^{\circ} \mathrm{C}$ with a TOS $=14 \mathrm{~h}$.

issues related to catalyst deactivation did exist; these are discussed in the next section.

\subsection{Deactivation of $\mathrm{Cu}$ /Beta catalyst during ethanol conversion}

To get more detailed information on the deactivation behaviors of the $5 \% \mathrm{Cu} /$ Beta catalyst in the ethanol-to-acetaldehyde reaction, the existing states of $\mathrm{Cu}$ species and organic deposits after the reaction were investigated using TEM, CO-DRIFTS, and TGA. As shown in Fig. 8(a), the agglomeration of $\mathrm{Cu}$ species occurred in the deactivated catalyst; large aggregates of about $25 \mathrm{~nm}$ could be observed. According to earlier reports [12,17], the main reason for the deactivation of $\mathrm{Cu}$ catalysts is $\mathrm{Cu}$ sintering. Therefore, in comparison with the state of a fresh catalyst, the agglomeration of $\mathrm{Cu}$ species in the spent $5 \% \mathrm{Cu} /$ Beta catalyst under study may have been a key reason for the catalyst deactivation.

The existing states of $\mathrm{Cu}$ species in the spent $5 \% \mathrm{Cu} / \mathrm{Beta}$ catalyst after ethanol-to-acetaldehyde conversion for $180 \mathrm{~h}$ were investigated using DRIFTS, with $\mathrm{CO}$ as the probe molecule. Fig. 8(b) shows the DRIFTS spectra of the spent $5 \%$

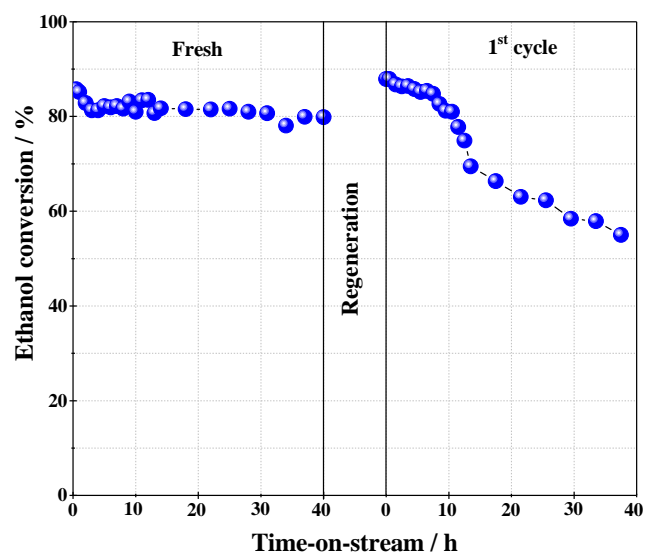

Fig. 7. Catalytic properties of regenerated $5 \% \mathrm{Cu} /$ Beta zeolite used as ethanol to acetaldehyde catalyst at $300^{\circ} \mathrm{C}$ with a TOS of $40 \mathrm{~h}$.
$\mathrm{Cu} /$ Beta catalyst after treatment with $2 \% \mathrm{CO}$ (He balanced) at 25,50 , and $100{ }^{\circ} \mathrm{C}$, followed by purging with He for $30 \mathrm{~min}$. Two dominant bands at 2119 and $2170 \mathrm{~cm}^{-1}$ appeared for all the spent $5 \% \mathrm{Cu} /$ Beta catalysts treated at different temperatures. The band at $2119 \mathrm{~cm}^{-1}$ with a shoulder at $2133 \mathrm{~cm}^{-1}$ could be attributed to either the $\mathrm{Cu}^{+}-\mathrm{CO}$ carbonyl species or the atop binding of $\mathrm{CO}$ on $\mathrm{Cu}$ surface atoms [14,22,37]. However, upon increasing the treatment temperature, the intensities of the bands at 2119 and $2133 \mathrm{~cm}^{-1}$ significantly decreased, whereas no obvious changes occurred for the band at 2170 $\mathrm{cm}^{-1}$. According to the literature, the $\mathrm{Cu}^{0}-\mathrm{CO}$ species can be easily removed during flushing or heating, whereas the $\mathrm{Cu}^{+}-(\mathrm{CO})_{x}$ carbonyl species are highly resistant to He flushing or heating [22]. Therefore, the band at 2119 with a shoulder at $2133 \mathrm{~cm}^{-1}$ should be assigned to $\mathrm{CO}$ binding to $\mathrm{Cu}$ surface atoms. The band at $2170 \mathrm{~cm}^{-1}$ could be attributed to $\mathrm{Cu}^{+}-(\mathrm{CO})_{2}$ dicarbonyl species. These results indicated that the $\mathrm{CuO}$ species confined in the [Si]Beta matrix could be gradually reduced to $\mathrm{Cu}^{+}$and $\mathrm{Cu}^{0}$ species during the ethanol dehydrogenation reaction. With an increase in the production of $\mathrm{Cu}^{2+}$, the selectivity to acetaldehyde gradually increased, as shown by the catalytic results (Fig. 5). This indicates that the presence of $\mathrm{Cu}^{+}$and $\mathrm{Cu}^{0}$ species is beneficial to the acetaldehyde selectivity; this is supported by the $\mathrm{H}_{2}$ pretreatment results. As shown in Fig. S1, after $\mathrm{H}_{2}$ pretreatment at 215 and $300{ }^{\circ} \mathrm{C}$, the acetaldehyde selectivity increases to more than $90 \%$, whereas the ethanol conversion obviously decreases. According to the TPR results (Fig. 2(d)), the $5 \% \mathrm{Cu} /$ Beta sample treated at $215{ }^{\circ} \mathrm{C}$ should contain $\mathrm{Cu}^{+}$species, whereas that treated at $300{ }^{\circ} \mathrm{C}$ mainly contains $\mathrm{Cu}^{0}$ species. This indicates that $\mathrm{Cu}^{2+}, \mathrm{Cu}^{+}$, and $\mathrm{Cu}^{0}$ species are all active in the ethanol dehydrogenation to acetaldehyde; however, the $\mathrm{Cu}^{+}$and $\mathrm{Cu}^{0}$ species are beneficial to the acetaldehyde selectivity. After the emergence of $\mathrm{Cu}^{0}$ nanoparticles due to over-reduction, metal sintering occurred, as revealed by the TEM pictures (Fig. 8(a)), leading to catalyst deactivation.

To quantify the carbon deposits formed on the $5 \% \mathrm{Cu} /$ Beta catalyst after the ethanol-to-acetaldehyde conversion for $180 \mathrm{~h}$, the weight contents of these deposits were determined using TGA in the temperature range of $25-800{ }^{\circ} \mathrm{C}$. In general, two obvious weight losses were recognized: a low-temperature weight loss at $<300{ }^{\circ} \mathrm{C}$ and a high-temperature weight loss at $>400{ }^{\circ} \mathrm{C}$. These were ascribed to volatile compounds and occluding coke compounds, respectively. According to Fig. 8(c), a small weight loss of about $0.32 \%$ due to the weakly adsorbed water and a weight loss of $3.07 \%$ attributable to the occluding carbon compounds appeared in the TGA curves. With regard to the catalytic performance of the regenerated catalyst (Fig. 7), the low weight losses of $3.07 \%$ had a minor impact on the catalyst deactivation under study. Additionally, a special wave curve with two weight gains appeared in the temperature range of $135-320{ }^{\circ} \mathrm{C}$. According to the standard TGA curves of blank $\mathrm{Cu}$ and $\mathrm{Cu}_{2} \mathrm{O}$ samples (Fig. 8(d)), the former weight gain in the temperature range of $135-225^{\circ} \mathrm{C}$ should have been due to the oxidation of $\mathrm{Cu}^{0}$, whereas the latter in the temperature range of $300-320{ }^{\circ} \mathrm{C}$ could be assigned to the oxidation of $\mathrm{Cu}^{+}$ species. These results indicate the presence of $\mathrm{Cu}$ and $\mathrm{Cu}^{+}$spe- 
(a)
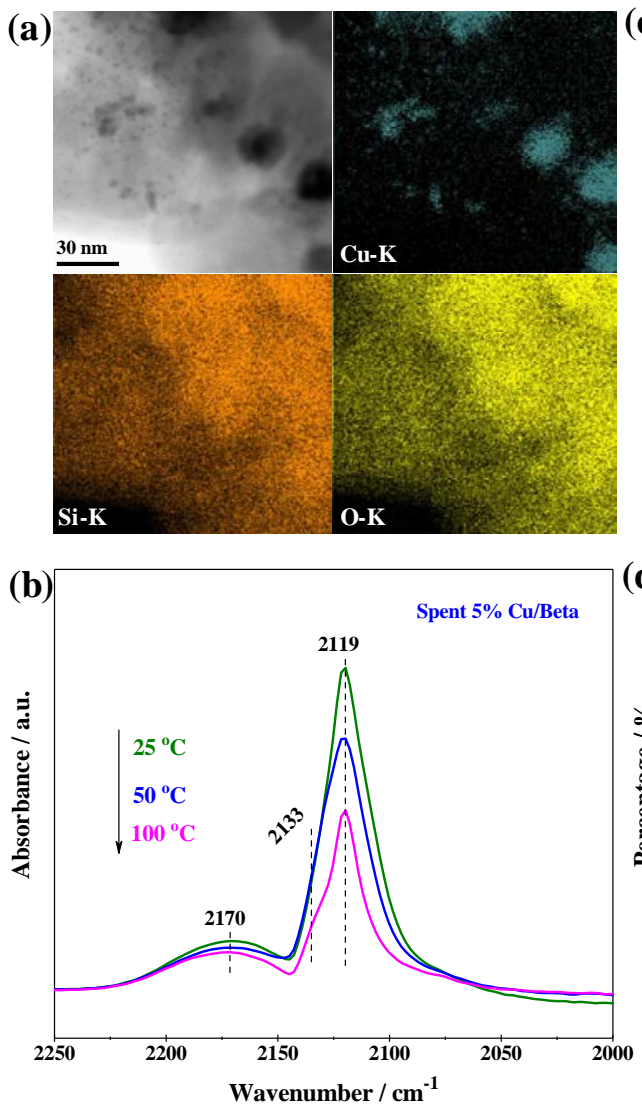

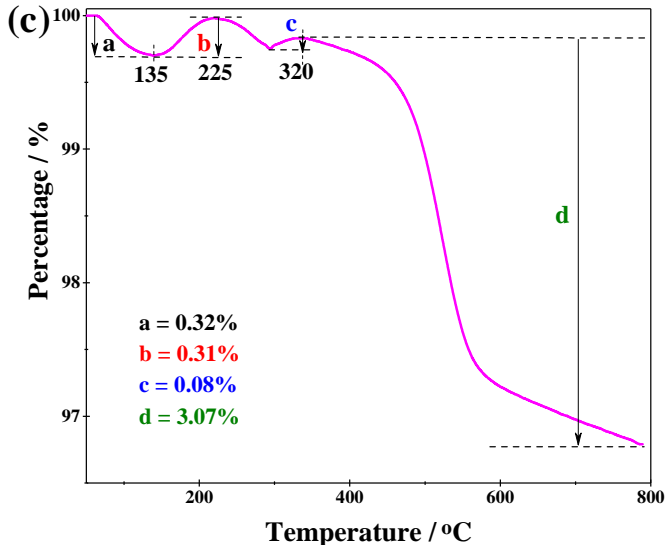

(d)

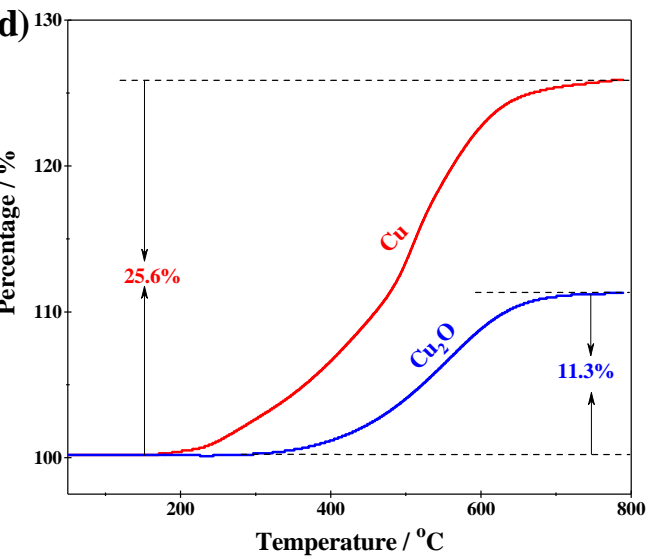

Fig. 8. TEM image and the corresponding element mapping (a), and CO-DRIFTS spectra (b) as well as TGA curves (c) of the spent $5 \%$ Cu/Beta zeolite catalyst obtained after the ethanol to acetaldehyde conversion at $300{ }^{\circ} \mathrm{C}$ with a TOS of $40 \mathrm{~h}$; (d) TGA curves of the bulk $\mathrm{Cu}$ and $\mathrm{Cu} 2 \mathrm{O}$ samples.

cies in the spent $5 \% \mathrm{Cu} /$ Beta catalyst after the reaction for 180 $\mathrm{h}$, again, in good agreement with the CO-DRIFTS results (Fig. 8(b)).

To summarize the results of the TEM, CO-DRIFTS, and TGA investigations, we came to the conclusion that the highly dispersed $\mathrm{Cu}^{2+}$ species confined in the [Si]Beta matrix could be gradually reduced to $\mathrm{Cu}^{+}$and $\mathrm{Cu}^{0}$ species during the ethanol-to-acetaldehyde conversion. With the emergence of $\mathrm{Cu}^{0}$ particles, $\mathrm{Cu}$ sintering would occur after the long-term reaction, causing catalyst deactivation (Scheme 1). However, in comparison with bulk $\mathrm{CuO}$, the $\mathrm{Cu} /$ Beta-confined catalyst constructed via the post-synthesis route under study exhibited much better structural stability against $\mathrm{Cu}$ sintering; furthermore, a long lifetime of $100 \mathrm{~h}$ with an acetaldehyde yield of $\sim 70 \%$ could be achieved.

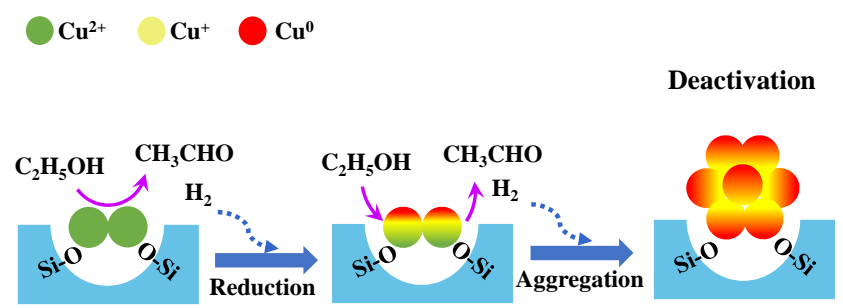

Scheme 1. Schematic illustration of the ethanol conversion on $\mathrm{Cu} / \mathrm{Beta}$ zeolite and its deactivation process.

\section{Conclusions}

In this work, copper species confined in [Si]Beta zeolite were prepared via a post-synthesis route and applied as catalysts for ethanol dehydrogenation to acetaldehyde. The homogeneous distribution of $\mathrm{Cu}$ species with tiny particles in the [Si]Beta matrix resulted in good structural stability against $\mathrm{Cu}$ sintering; a long lifetime of $100 \mathrm{~h}$ with an acetaldehyde yield of $\sim 70 \%$ could be achieved over the $5 \% \mathrm{Cu} /$ Beta catalyst. However, in the long-term reaction, the confined $\mathrm{CuO}$ species were gradually reduced to $\mathrm{Cu}^{+}$and $\mathrm{Cu}^{0}$ species, and the agglomeration of metallic $\mathrm{Cu}$ particles occurred, eventually leading to catalyst deactivation.

\section{Acknowledgments}

This work was supported by the National Natural Science Foundation of China (21872072, 21573113), Municipal Natural Science Foundation of Tianjin (18JCZDJC37400) and Sinopec (417012).

\section{References}

[1] C. Angelici, B. M. Weckhuysen, P. C. A. Bruijnincx, ChemSusChem, 2013, 6, 1595-1614. 


\section{Graphical Abstract}

Chin. J. Catal., 2019, 40: 1375-1384 doi: S1872-2067(19)63378-4

Stabilizing copper species using zeolite for ethanol catalytic dehydrogenation to acetaldehyde

Dongni Yu, Weili Dai *, Guangjun Wu, Naijia Guan, Landong Li*

Nankai University

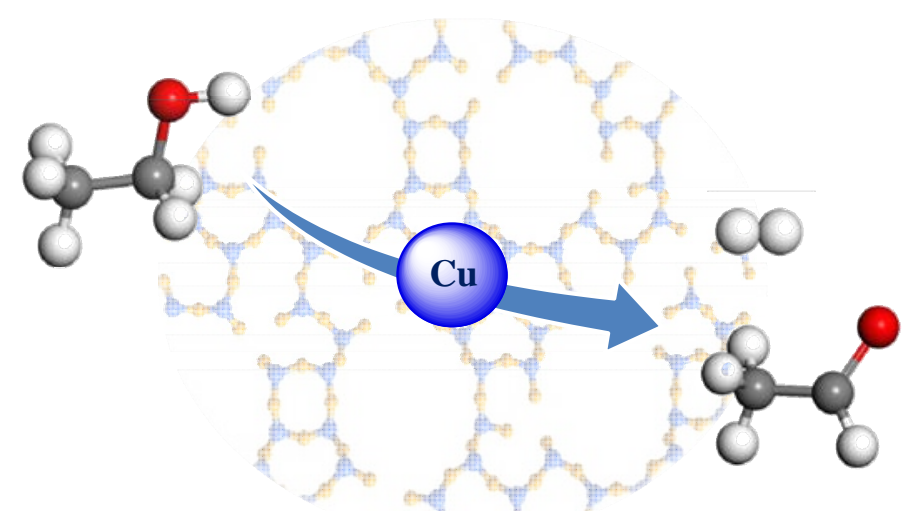

Catalyst lifetime: 100 h; Acetaldehyde yield : $70 \%$

$\mathrm{A} \mathrm{Cu} /$ Beta confined catalyst constructed via the post-synthesis route exhibited good structural stability against $\mathrm{Cu}$ sintering; a long lifetime of $100 \mathrm{~h}$ with an acetaldehyde yield of $\sim 70 \%$ could be achieved.

[2] J. Sun, Y. Wang, ACS Catal., 2014, 4, 1078-1090.

[3] H. J. Hagemeyer, Acetaldehyde Kirk Othmer Encyclopedia of Chemical Technology, John Wiley \& Sons, Inc, Hoboken, NJ, USA, 2002.

[4] W. H. Lin, H. F. Chang, Catal. Today, 2004, 97, 181-188.

[5] H. Amandusson, L. G. Ekedahl, H. Dannetun, J. Catal., 2000, 195, 376-382.

[6] Y. Q. Liang, Z. D. Cui, S. L. Zhu, Y. Liu, X. J. Yang, J. Catal., 2011, 278, 276-287.

[7] V. L. Sushkevich, I. I. Ivanova, E. Taarning, ChemCatChem, 2013, 5, 2367-2373.

[8] S. P. Tonner, D. L. Trimm, M. S. Wainwright, N. W. Cant, Ind. Eng. Chem. Prod. Res. Dev., 1984, 23, 384-388.

[9] Y. Guan, E. J. M. Hensen, Appl. Catal. A, 2009, 361, 49-56.

[10] S. Sitthisa, D. E. Resasco, Catal. Lett., 2011, 141, 784-791.

[11] Y. J. Tu, Y. W. Chen, Ind. Eng. Chem. Res., 1998, 37, 2618-2622.

[12] Y. J. Tu, Y. W. Chen, Ind. Eng. Chem. Res., 2001, 40, 5889-5893.

[13] Q. N. Wang, L. Shi, A. H. Lu, ChemCatChem, 2015, 7, 2846-2852.

[14] J. J. Shan, N. Janvelyan, H. Li, J. L. Liu, T. M. Egle, J. C. Ye, M. M. Biener, J. Biener, C. M. Friend, M. Flytzani-Stephanopoulos, Appl. Catal. B, 2017, 205, 541-550.

[15] Q. N. Wang, L. Shi, W. Li, W. C. Li, R. Si, F. Schüth, A. H. Lu, Catal. Sci. Technol., 2018, 8, 472-479.

[16] M. E. Witzke, J. P. Dietrich, M. Y. S. Ibrahim, K. Al-Bardan, M. D. Triezenberg, D. W. Flaherty, Chem. Commun., 2017, 53, 597-600.

[17] F. W. Chang, H. C. Yang, L. S. Roselin, W. Y. Kuo, Appl. Catal. A, 2006, 304, 30-39.

[18] M. Ai, Appl. Catal., 1984, 11, 259-270.

[19] Y. J. Tu, Y. W. Chen, C. P. Li, J. Mol. Catal., 1994, 89, 179-189.

[20] S. W. Colley, J. Tabatabaei, K. C. Waugh, M. A. Wood, J. Catal., 2005, 236, 21-33.
[21] E. Santacesaria, G. Carotenuto, R. Tesser, M. Di Serio, Chem. Eng. J., 2012, 179, 209-220.

[22] I. C. Freitas, S. Damyanova, D. C. Oliveira, C. M. P. Marques, J. M. C. Bueno, J. Mol. Catal. A, 2014, 381, 26-37.

[23] W. H. Cassinelli, L. Martins, A. R. Passos, S. H. Pulcinelli, A. Rochet, V. Briois, C. V. Santilli, ChemCatChem, 2015, 7, 1668-1677.

[24] W. H. Cassinelli, L. Martins, M. Magnani, S. H. Pulcinelli, V. Briois, C. V. Santilli, RSC Adv., 2016, 6, 20453-20457.

[25] R. Z. Li, M. H. Zhang, Y. Z. Yu, Appl. Surf. Sci., 2005, 236, 21.

[26] F. W. Chang, W. Y. Kuo, K. C. Lee, Appl. Catal. A, 2003, 246, 253-264.

[27] F. Wang, R. J. Shi, Z. Q. Liu, P. J. Shang, X. Y. Pang, S. Shen, Z. C. Feng, C. Li, W. J. Shen, ACS Catal., 2013, 3, 890-894.

[28] I. Rossetti, C. Biffi, C. L. Bianchi, V. Nichele, M. Signoretto, F. Menegazzo, E. Finocchio, G. Ramis, A. Di Michele, Appl. Catal. B, 2012, 117-118, 384-396.

[29] M. Y. Li, W. D. Lu, L. He, F. Schüth, A. H. Lu, ChemCatChem, 2018, 11, 481-487.

[30] W. L. Dai, S. S. Zhang, Z. Y. Yu, T. T. Yan, G. J. Wu, N. J. Guan, L. D. Li, ACS Catal., 2017, 7, 3703-3706.

[31] T. T. Yan, W. L. Dai, G. J. Wu, S. Lang, M. Hunger, N. J. Guan, L. D. Li, ACS Catal., 2018, 8, 2760-2773.

[32] T. T. Yan, L. Yang, W. L. Dai, C. M. Wang, G. J. Wu, N. J. Guan, M. Hunger, L. D. Li, J. Catal., 2018, 367, 7-15.

[33] B. Tang, W. L. Dai, G. J. Wu, N. J. Guan, L. D. Li, M. Hunger, ACS Catal., 2014, 4, 2801-2810.

[34] B. Tang, W. L. Dai, X. M. Sun, N. J. Guan, L. D. Li, M. Hunger, Green Chem., 2014, 16, 2281-2291.

[35] B. Tang, W. L. Dai, X. M. Sun, G. J. Wu, N. J. Guan, M. Hunger, L. D. Li, Green Chem., 2015, 17, 1744-1755.

[36] B. Tang, W. L. Dai, X. M. Sun, G. J. Wu, N. J. Guan, L. D. Li, M. Hunger, 
Chin. J. Catal., 2015, 36, 801-805.

[37] L. Xu, C. Shi, Z. S. Zhang, H. Gies, F. S. Xiao, D. Des Vos, T. Yokoi, X. H. Bao, M. Feyen, S. Maurer, B. Yilmaz, U. Müller, W. P. Zhang, Microporous Mesoporous Mater., 2014, 200, 304-310.
[38] S. A. Yashnik, Z. R. Ismagilov, V. F. Anufrienko, Catal. Today, 2005, $110,310-322$.

[39] S. Kieger, G. Delahay, B. Coq, B. Neveu, J. Catal., 1999, 183, 267-280.

\title{
分子篮稳定的Cu物种催化乙醇脱氢制乙醛
}

\author{
于东霓 ${ }^{\mathrm{a}}$, 戴卫理 ${ }^{\mathrm{a},}{ }^{*}$, 武光军 ${ }^{\mathrm{a}}$, 关乃佳 ${ }^{\mathrm{a}, \mathrm{b}}$, 李兰冬 ${ }^{\mathrm{a}, \mathrm{b}, \#}$ \\ a南开大学材料科学与工程学院, 国家新材料研究院, 天津 300350 \\ b南开大学先进能源材料化学教育部重点实验室, 化学化工协同创新中心, 天津 300071
}

\begin{abstract}
摘要: 生物乙醇作为一种绿色原料, 常用于制备具有更高附加值的化学品, 如乙烯、丙烯、丁二烯、1-丁醇和乙醛等. 其中, 乙醛作为重要的化学原料又可以进一步转化生成乙酸, 乙酸酯和季戊四醇等。因此, 由生物乙醇脱氢制乙醛的可持续路线 受到了研究者的广泛关注. 在众多催化体系中, $\mathrm{Cu}$ 基催化剂表现出较高的活性和乙醛选择性, 但 $\mathrm{Cu}$ 物种的烧结又会导致催 化剂的快速失活. 因此, 抑制 $\mathrm{Cu}$ 物种的烧结是提高 $\mathrm{Cu}$ 基催化剂稳定性的常用手段. 本文通过后合成路线构筑了具有限域 效应的 $\mathrm{Cu} / \mathrm{Beta}$ 分子篮催化剂, 并成功应用于乙醇脱氢制乙醛反应. 我们首先考察了 $\mathrm{Cu}$ 的负载量、反应温度和 $\mathrm{Cu}$ 的前驱体 对反应的影响, 发现以醋酸铜为前驱体的 $5 \% \mathrm{Cu} / \mathrm{Beta}$ 催化剂在乙醇脱氢制乙醛反应中表现出最佳催化性能: 催化剂寿命达 到 $100 \mathrm{~h}$, 乙醛收率稳定在 $70 \%$ 左右 (反应条件: $300{ }^{\circ} \mathrm{C}, \mathrm{WHSV}=1.0 \mathrm{~h}^{-1}$ ). XRD, TEM, DRIFT, ${ }^{1} \mathrm{H}$ MAS NMR, UV-Vis以及 $\mathrm{H}_{2}$-TPR等结果表明以醋酸铜为前驱体的 Cu/Beta分子篮上的主要活性中心为 $\mathrm{CuO}$ 物种, 并且该物种以高度分散的形式限域 在分子篮脱铝产生的硅羟基缺陷位上. 因此, 在乙醇脱氢制乙醛反应中, 限域的 $\mathrm{Cu} / \mathrm{Beta}$ 分子筛催化剂与孤立的 $\mathrm{CuO}$ 催化剂 相比, 具有优异的抗烧结能力. 然而, 当反应至 $180 \mathrm{~h}$ 时, 催化剂会有明显的失活现象. 再生后, 尽管催化剂的初始活性能较 好的恢复, 但催化剂的寿命却大大下降. 我们利用TEM, TGA以及CO-DRIFTS对反应后的催化剂进行表征, 发现失活的 $\mathrm{Cu} / \mathrm{Beta}$ 催化剂上存在 $\mathrm{Cu}^{+}$和 $\mathrm{Cu}^{0}$ 物种, 并且伴有大块烧结现象. 这表明随着反应的进行, $\mathrm{Cu} / \mathrm{Beta}$ 催化剂上的 $\mathrm{CuO}$ 物种会逐渐 还原成 $\mathrm{Cu}^{+}$和 $\mathrm{Cu}^{0}$ 物种, 而 $\mathrm{Cu}^{0}$ 物种的出现又会诱导烧结现象的发生, 进而导致催化剂的失活.
\end{abstract}

关键词: 乙醇脱氢; 乙醛; 沸石分子篮; Cu基催化剂; 失活

收稿日期: 2019-02-28. 接受日期: 2019-04-02. 出版日期: 2019-09-05.

*通讯联系人. 电话/传真: (022)85358536; 电子信箱: weilidai@nankai.edu.cn

\#通讯联系人. 电话/传真: (022)23500341; 电子信箱: lild@nankai.edu.cn

基金来源：国家自然科学基金(21872072, 21573113); 天津市自然科学基金(18JCZDJC37400); 中国石化(417012).

本文的电子版全文由Elsevier出版社在ScienceDirect上出版(http://www.sciencedirect.com/science/journal/18722067). 